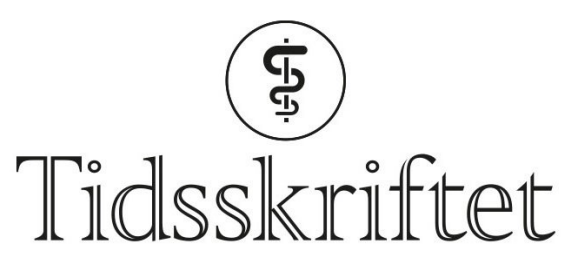

DEN NORSKE LEGEFORENING

\title{
Kan RNA brukes til å anslå dødstidspunkt?
}

FRA ANDRE TIDSSKRIFTER

RUTH HALSNE

Tidsskriftet

Ved død vil de biokjemiske prosessene i kroppen fortsette før de endres og til slutt stopper. Kan en profil over RNA-transkripsjon brukes til å anslå dødstidspunktet?

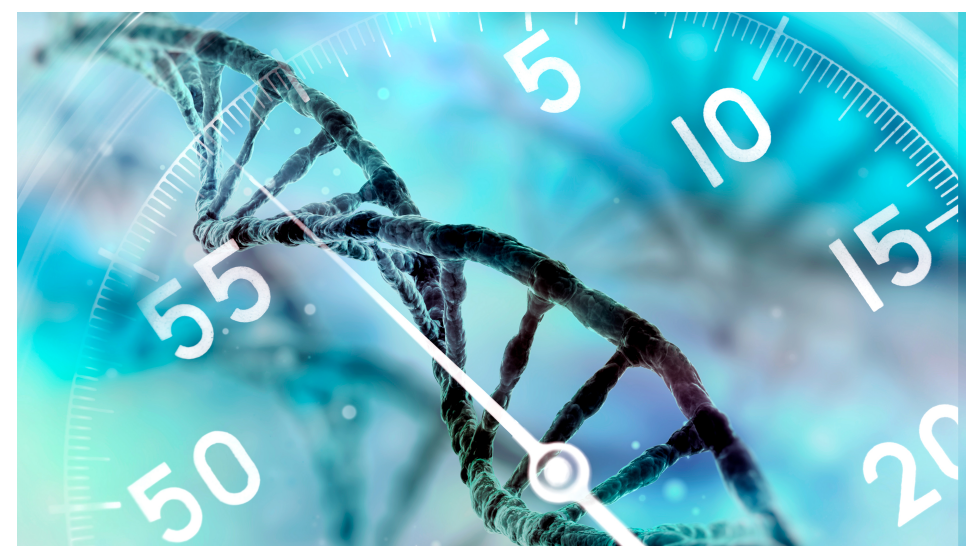

Illustrasjonsfoto: Collage av cosmin4ooo/iStock og amriphoto/iStock

RNA-sekvenseringsdata fra forskjellige vev fra til sammen 540 personer post mortem ble brukt til å studere endringer i transkripsjonsprofiler ved ulike intervaller etter dødstidspunktet (1). Forskerne hadde også tilgang på sekvenseringsdata fra blodprøver, tatt både før og etter at døden inntraff.

Den mest markerte endringen i genekspresjon skjedde ca. seks timer post mortem. Det var lite overlapp i hvilke gener som var påvirket i de ulike vevene. Ved analyse av transkripsjonsprofiler i blod ble det avdekket at hovedfunksjoner var endret, slik som DNAsyntese, deaktivert immunrespons, prosesser som styrer nekrose, inaktivering av lipidsyntese og ionetransport. Dette kan bety at transkripsjonen er regulert post mortem. Basert på profileringsdataene og sammenligning av flere vev ble det utviklet en algoritme som kunne anslå dødstidspunktet. Algoritmen var mest presis de første timene post mortem.

- Denne studien gir en flott beskrivelse av endringer i RNA- uttrykk som skjer i ulike vev etter døden, noe som er nyttig i mange forskningssammenhenger, sier Asbjørg StrayPedersen og Arne Stray-Pedersen, som er overleger ved Nyfødtscreeningen og Rettsmedisinsk institutt ved Oslo universitetssykehus. - Men deretter viser de en nokså futuristisk og virkelighetsfjern metode der dette RNA-uttrykket skal brukes til å vurdere 
dødstidspunkt. Noe tilsvarende er tidligere forsøkt i etterkant av en rekke nye analysemetoder, forteller de, der det viste seg at omstendighetene rundt dødsfallet, særlig omgivelsestemperaturen, var avgjørende for hvor raskt de biologiske prosessene foregår etter at blodsirkulasjonen opphører, og da er usikkerheten stor.

\section{LITTERATUR:}

1. Ferreira PG, Muñoz-Aguirre M, Reverter F et al. The effects of death and post-mortem cold ischemia on human tissue transcriptomes. Nat Commun 2018; 9: 49o. [PubMed][CrossRef]

Publisert:3. september 2018. Tidsskr Nor Legeforen. DOI: 10.4045/tidsskr.18.0443

(C) Tidsskrift for Den norske legeforening 2020. Lastet ned fra tidsskriftet.no 